\title{
Petrographic and geochemical study on cave pearls from Kanaan Cave (Lebanon)
}

Fadi H. Nader ${ }^{1}$

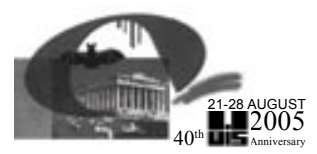

Paper presented during the 14th International Congress of Speleology, Kalamos (Greece) 21-28 August 2005.

\begin{abstract}
:
Nader F.H. 2007. Petrographic and geochemical study on cave pearls from Kanaan Cave (Lebanon).

International Journal of Speleology, 36 (1), 39-50. Bologna (Italy). ISSN 0392-6672.
\end{abstract}

The Kanaan cave is situated at the coastal zone, north of Beirut City (capital of Lebanon). The cave is located within the upper part of the Jurassic Kesrouane Formation (Liassic to Oxfordian) which consists mainly of micritic limestone. Twenty seven cave pearls were subjected to petrographic (conventional and scanning electron microscopy) and geochemical analyses (major/trace elements and stable isotopes). The cave pearls were found in an agitated splash-pool with low mud content. They are believed to have formed through chemical precipitation of calcite in water over-saturated with calcium. The nucleus and micritic laminae show $\delta^{18} \mathrm{O}_{V-P D B} v{ }^{2}$ lues of about $-5.0 \%$ and $\delta^{13} C_{V-P D B}$ values of $-11.8 \%$, while the surrounding calcite spar laminae resulted in $\delta^{18} \mathrm{O}_{V-P D B}$ ranging between -5.3 and $-5.2 \%$, and $\delta^{13} \mathrm{C}_{\mathrm{V}-\mathrm{PDB}}$ between -12.3 and $-12.1 \%$. A genesis/diagenesis model for these speleothems is proposed involving recrystallization which has selectively affected the inner layers of the cave pearls. This is chiefly invoked by sparry calcite crystals 'invading' the inner micrite cortical laminae and the nuclei (cross-cutting the pre-existing mud-envelopes), and the slight depletion in $\delta^{18} \mathrm{O}$ values from inner to outer cortical layers. The calculated $\delta^{18} \mathrm{O}_{\mathrm{V} \text {-smow }}$ of the water $(-4.2 \% 0)$ matches with data on meteoric water signature for the central eastern Mediterranean region.

Keywords: Speleothems, diagenesis, aggradational crystal growth, $\delta^{18} \mathrm{O}$, Lebanon.

Received 5 May 2006; Revised 14 October 2006; Accepted 14 November 2006

\section{INTRODUCTION}

A considerable amount of papers have documented concentrically laminated grains - termed as cavepisoids, or pearls - found in low energy rimstone pools and high energy splash pools in caves (e.g. Baker \& Frostick, 1947; Gradzinski \& Radomski, 1967; Donahue, 1969; Jones \& Kahle, 1986; Jones \& MacDonald, 1989; Hill \& Forti, 1997 and references herein; Gradzinski, 2001). Only a very few contributions, strictly descriptive, have reported similar cave speleothems from the Middle-East (e.g. Abdul-Nour, 1991; Choppy, 1991; Karkabi, 1991). This contribution presents results of the first petrographic and geochemical studies on cave pearls found in Lebanon - collected from the Kanaan cave (central Lebanon). New data about the formation of this type of speleothems in a typical Mediterranean setting is provided. Also, the various controlling factors on the genesis and growth of cave pearls with a special focus on the inherent role of diagenesis are discussed.

\footnotetext{
${ }^{1}$ Department of Geology, American University of Beirut, PO

Box: 11-0236/26 Beirut, Lebanon

Spéléo-Club du Liban, PO Box: 70-923 Antelias, Lebanon.

E-mail: fadi.nader@aub.edu.lb
}

\section{GEOLOGICAL BACKGROUND}

Lebanon covers $10452 \mathrm{~km}^{2}$ of surface area and stretches along the central eastern coast of the Mediterranean Sea (Fig. 1A). Geomorphologically, it consists of two mountain chains (Mount-Lebanon and Anti-Lebanon) separated by a high inland plain (the Bekaa; Fig. 1A). The western chain (MountLebanon) borders the Mediterranean Sea, displaying relatively gentle slopes on its western flanks and steeper ones on its eastern flanks. The highest point in Lebanon is located in the northern part of this mountain chain; i.e. the Qornet es Saouda, 3083 m above sea level (asl). Precipitation (rain and snow) falls in abundance on the Lebanese mountain chains, especially on Mount-Lebanon. The precipitation rate varies between 700 and $1200 \mathrm{~mm} /$ year with increasing elevations (i.e. higher altitudes) across Mount-Lebanon, and about $80 \%$ of the yearly precipitation falls from November through February (Edgell, 1997).

Carbonate rocks (limestone and dolostone) dominate the known Lebanese rock succession. The oldest exposed rocks are of Liassic age (part of the Early-Middle Jurassic Kesrouane Formation; Dubertret, 1975). The Jurassic strata constitute 


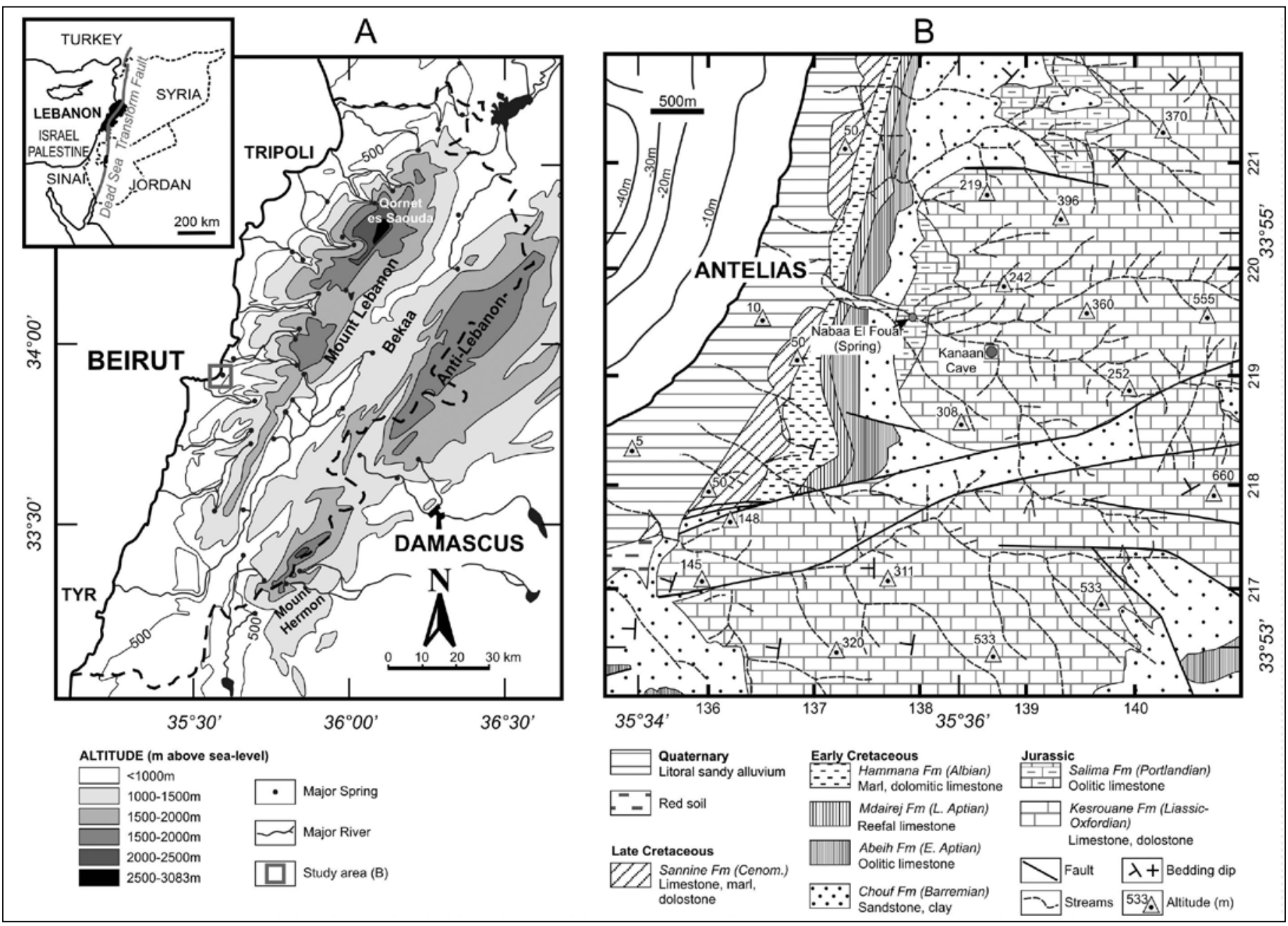

Fig. 1. Simplified topographic map of Lebanon (A) - inset map showing the position of Lebanon in the Levant Region. (B) Geological map showing the location of the Kanaan cave - modified from Dubertret (1955) and Walley (1997).

the cores of the Mount-Lebanon and Anti-Lebanon. The Cretaceous strata - especially the CenomanianTuronian Sannine and Maameltain Formations - form the flanks of the mountain chains, covering most of the country surface-area. The stratigraphy of Lebanon has been investigated by a number of authors; e.g. Dubertret (1955), Saint-Marc (1974 and 1980), Walley (1997), Beydoun (1988), and Nader (2000).

The Late Jurassic is characterized by a period of regional uplift, emergence and erosion. Upon emergence, the Jurassic rock-mass was deeply fractured and karstified before volcanism took place. Subsequently, volcanic deposits and continental debris filled-up the pre-existing fractures and depressions accentuating the palaeotopography (Renouard, 1955; Nader et al., 2003). During the Cretaceous times, the Early Jurassic strata were buried to a depth reaching $3 \mathrm{~km}$ (Nader et al., 2004). The final uplift of Mount-Lebanon mainly occurred during the Oligocene (Dubertret, 1975; Nader \& Swennen, 2004). Since the Miocene, the morphology of Mount-Lebanon was not very different than that of today (Dubertret, 1975; Walley, 2001). Subsequently, karstification, part of the meteoric diagenesis processes, is expected to have affected the exposed Mount Lebanon at least since that time (i.e. Miocene).

\section{KANAAN CAVE SETTINGS}

The Kanaan cave is located in the Kassarat area to the east of the coastal town of Antelias, a few kilometers north of Beirut City (capital of Lebanon; Fig. 1B). The cave is located within the deeply and intensively karstified rocks of the Kesrouane Formation (Fig. 1B). The deepest known sinkholes (Houet Fouar ed Dara, $-622 \mathrm{~m}$ and Houet Qattine Azar, $-450 \mathrm{~m}$ ) as well as the longest cave in Lebanon (Magharet Jeita, $9 \mathrm{~km}$ ) are found within this rock unit. The Kanaan cave was discovered in 1997, when its entrance became exposed during rock-quarrying. The entrance is situated at around $100 \mathrm{~m}$ above sealevel, almost at the foot of a steep limestone cliff with a height exceeding $150 \mathrm{~m}$ (Fig. 2A). The monotonous blue-grey (fossiliferous) micritic limestone lithology characterizing the Kesrouane Formation (Dubertret, 1975; Walley, 1997) is, nevertheless, disrupted with minor clayey/marly horizons - in some places evidence supporting paleosols and subaerial exposure were also suggested (see Nader \& Swennen, 2004). A marly horizon, rich in brachiopods, including relatively thin seams of coal, was observed underlying the Kanaan cave entrance and its underground network. This horizon provides a local, impermeable substratum for karstification, playing an important hydrogeological role with respect to the cave speleogenesis.

The Kanaan cave, which amounts to some $120 \mathrm{~m}$ 


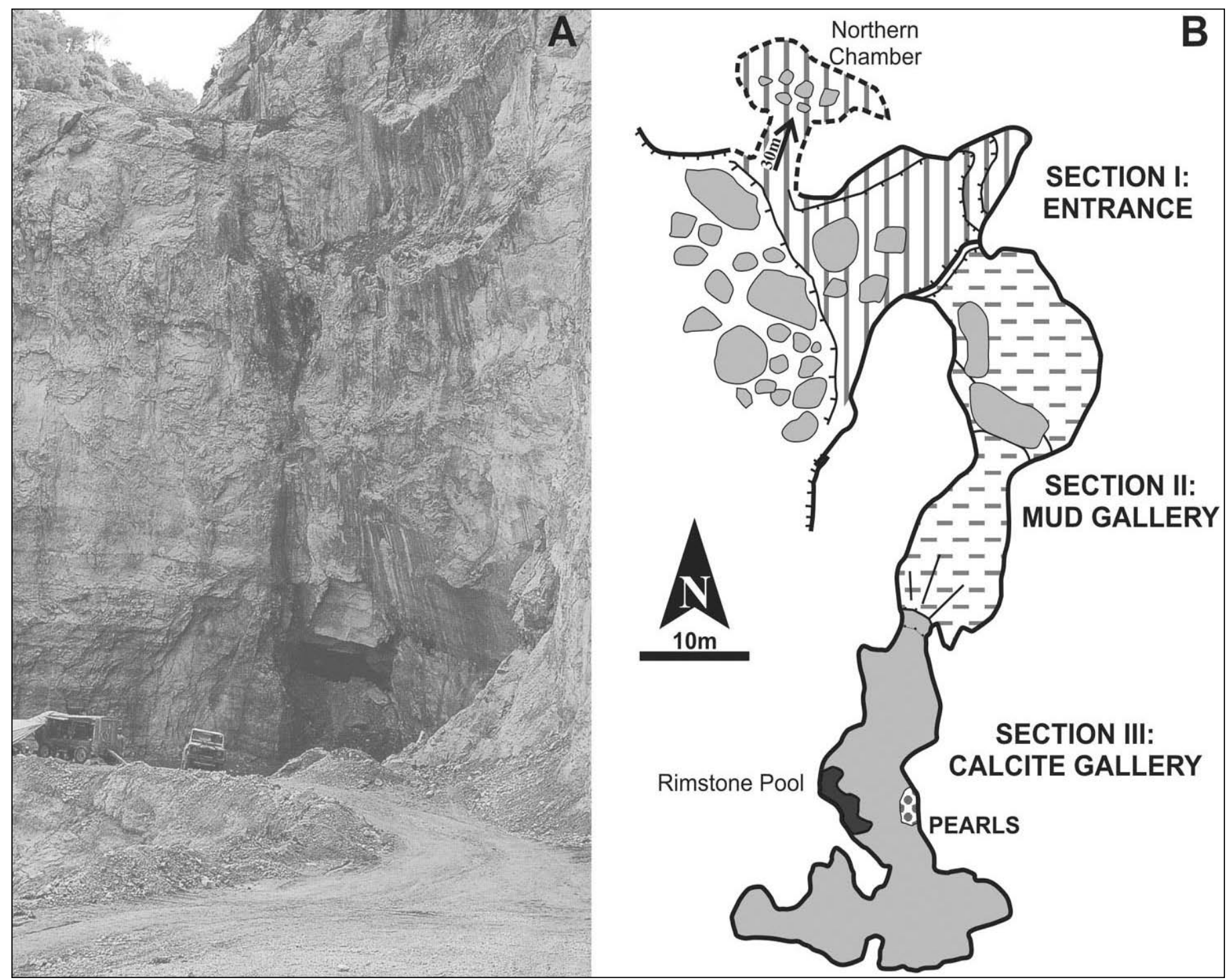

Fig. 2. The Kanaan cave, Antelias - central Lebanon: (A) Photograph showing the cave entrance, photo facing east - photo by Hughes Badaoui; (B) cave survey showing the three distinct sections and the location of the cave pearls (from Nader, 1998).

of underground passages and chambers, is divided into three parts (Fig. 2B): (i) the Entrance, (ii) the Mud Gallery, and (iii) the Calcite Gallery. The cave entrance overlies a rock-collapse slope (quarrying debris) and forms an artificial direct access (due to quarrying) to a room with a high chimney, hosting a community of bats. A low passage trending northward leads to another room with another chimney (ca. the Northern Chamber, Fig. 2B). The Mud Gallery is named after the considerable amount of mud existing in this part of the cave forming small hills of slippery mud. Here, relatively thick rock slabs (with thickness exceeding $1 \mathrm{~m})$ collapsed from the cave-ceiling. These massive limestone rocks lay randomly on the cave-floor that is covered with mud. The southernmost part of the Kanaan cave, the Calcite Gallery, is loaded with a wide variety of speleothems. It consists of a big hall with a high ceiling (more than $20 \mathrm{~m}$ ) and a lateral development with reverse " 7 " shape (see Fig. 2B). The floor is calcitic and overlies brown mud that is similar to the mud found in the Mud Gallery). A wide diversity of speleothems is observed (stalagmites, stalactites, helictites, 'curtains', flowstones, rimstone pools, among others). The investigated cave pearls were collected from the middle part of this hall (Fig. 2B; Fig. 3A, B). Here, the calcitic floor is wet and includes small depressions hosting cave pearls (Fig. 3C, D). To the opposite side, a relatively large, but shallow, water pool exists (Fig. 2B).

\section{MATERIAL AND METHODS}

Twenty-seven cave pearls were collected from the Kanaan cave. Petrographic observations included conventional microscopy and scanning electron microscopy. $\mathrm{Ca}, \mathrm{Mg}, \mathrm{Na}, \mathrm{Sr}, \mathrm{Fe}, \mathrm{Mn}, \mathrm{Zn}$, and $\mathrm{K}$ concentrations in powdered samples, micro-drilled from the various concentric growth layers within cave pearls, were analyzed by flame atomic absorption spectrometry (AAS). Powdered samples (1g of each) were leached in $40 \mathrm{ml}$ (1 molar) $\mathrm{HCl}$ and left on hot plates until evaporation - the strength of the acid was chosen to be as low as possible in order to leach the minimum possible quantity of the noncarbonate fraction. The residues were dissolved for a second time in $20 \mathrm{ml}$ ( 1 molar) $\mathrm{HCl}$, then filtrated and diluted before AAS analysis. Analytical precision was generally better than $10 \%$ at the $95 \%$ confidence level, 
and the detection limit was 1 ppm. Water, sampled from the cave pools, was also subjected to chemical analyses (including $\mathrm{Ca}, \mathrm{Mg}, \mathrm{Na}, \mathrm{Sr}, \mathrm{Fe}, \mathrm{Mn}, \mathrm{Zn}$, and $\mathrm{K}$ concentrations). Various diagenetic phases were microsampled for measurement of their carbon and oxygen stable isotopic composition. Stable isotope analyses were done at the University of Erlangen - Germany (Institute of Geology and Mineralogy). The carbonate powders were subjected to reaction with phosphoric acid (density >1.9; Wachter \& Hayes, 1985) at $75^{\circ} \mathrm{C}$ in an online carbonate preparation line (Carbo-Kiel - single sample acid bath) connected to a Finnigan Mat 252 mass-spectrometer. All values are reported in per mil (\%o) relative to Vienna Pee Dee Belemnite (V-PDB). Reproducibility based on replicate analysis of laboratory standards is better than $\pm 0.02 \%$ o for $\delta^{13} \mathrm{C}$ and $\pm 0.03 \%$ o for $\delta^{18} \mathrm{O}$.

\section{KANAAN CAVE PEARLS}

The approach followed by Jones \& MacDonald (1989) to characterize cave pearls according to their size and shape, external appearance, nucleus, and cortical laminae is applied here as well. The observed and collected Kanaan pearls range in size from about 1 to $3 \mathrm{~cm}$ (with rare exceptions exceeding $5 \mathrm{~cm}$; Figs. $3 \& 4)$. The shape of these cave pearls varies between spherical, subspherical (with one side almost flat), and ellipsoidal forms. Some of them are attached to the calcitic floor (Fig. 3C, D). The great majority of the observed cave pisoids show an external smooth, wellpolished, lustrous morphology (Fig. 3C) - advocating their classification as 'cave pearls' (Baker \& Frostick, 1947; Donahue, 1969; Hill \& Forti, 1997). Less commonly, some cave pearls show rough, irregular crenulated surfaces made up of tiny trigonal calcite crystals (Fig. 4).

The majority of the cut and polished cave pearls show distinct, relatively spherical nuclei (Fig. 5). Only a few samples revealed elongated ellipsoidal nuclei irrespectively of the external shape of the cave pearls. The nuclei are relatively small with respect to the cave pearls (less than $10 \mathrm{~mm}$; Fig. 5). Yet, a relatively thick, yellowish aureole usually surrounds the nucleus. The investigated cave pearls revealed several concentric growth layers around the nuclei. These cortical laminae consist of a repetition of grayish translucent and massive milky white laminae (Fig. 5). The number of these growth zones (and their thickness) is not related to the size of the cave pearls (Fig. 5).

\section{PETROGRAPHY}

Five thin-sections were prepared out of the twentyseven sampled cave pearls. The thin-sections were stained with alizarin red $\mathrm{S}$, confirming that the cave pearls consist only of calcite. They were examined with conventional microscopic techniques.

The thin-sections show two types of cave pearl nuclei. In the first group, the nucleus is elliptical in shape. It consists of terra-rossa with some pyrite (opaque minerals shining under induced light) and probable organic matter as well as oxides/ hydroxides (yellowish-brown stained material; Fig. $6 \mathrm{~A})$. In the second group, the nucleus is made up of clear micritic, anhedral calcite crystallites including clear calcite spars (Fig. 6B, C). Relatively thin, dark cortical laminae envelop the nucleus displaying micritic calcite and a considerable amount of terrarossa. In both cases, the nucleus is surrounded by an aureole of darkish (impurity-rich) micritic calcite. It is worth mentioning that the second group of cave pearls clearly shows under polarized view a divergent outward, pseudo-uniaxial cross extinction (Fig. 6D), resulting from the convergent fabric of elongated columnar or "palisade" length-fast calcite crystals (cf. Kendall \& Tucker, 1973; Folk \& Assereto, 1976).

The cortical laminae which are close to the nucleus (inner laminae) consist of micritic calcite crystals (often trigonal in shape; Fig. 7A, B). Here the intercrystalline porosity is occluded with impurities (probably terra-rossa, clay and/or organic matter). The outer cortical laminae consist of elongated, radial, sparry calcite crystals (size exceeding 1 mm; Fig. 7C, D) similar to length-fast (palisade) calcite crystals (cf. Folk \& Assereto, 1976), with the original intercrystalline porosity occluded by other generations of calcite spars. Similar crystal fabrics were called 'feather-like calcite crystals' by Gradzinski \& Radomski (1967) and 'dendrite calcite crystals' by Jones \& MacDonald (1989). Alternatively, the growth competition may have resulted in similar textures where some crystals did not grow fast as the others, and remained of smaller sizes due to lack of space (Fig. 7C, D). Fig. 8A shows the transition from inner micritic calcite cortical laminae to outer sparry calcite laminae. A faint syntaxial growth is revealed, as the same extinction is displayed. The impurity-rich thin layer (mud-cover) separating these cortical laminae show a discontinuous pattern, where extensions of the sparry calcite crystals prevail (Fig. 8B). This pattern - i.e. the local removal of impurity-rich thin laminae - suggests that recrystallization during and/or after the sparry calcite formation must have occurred.

The external morphology of the cave pearls was mainly investigated through scanning-electron microscopy (Fig. 9A, B). The calcite crystals of the outermost growth layer display a general trigonal morphology (crystal size: 150 to $500 \mu \mathrm{m}$ ). Further investigation show that the apexes of these crystals are rhombohedra faces that are combined to the trigonal prism faces (Fig. 9A, B). This crystalline framework results in a considerable amount of intercrystalline porosity (Fig. 9A). Further investigations of the calcite crystals revealed that they consist of several generations of smaller, embedded trigonal crystals welded together (Fig. 9B). This could be viewed as an aggradational crystal growth, keeping the same crystalline morphology and leading to larger crystals. Note that the sharp extremities of the trigonal crystals are often broken, probably due to corrosion induced by movement of the pearl. 

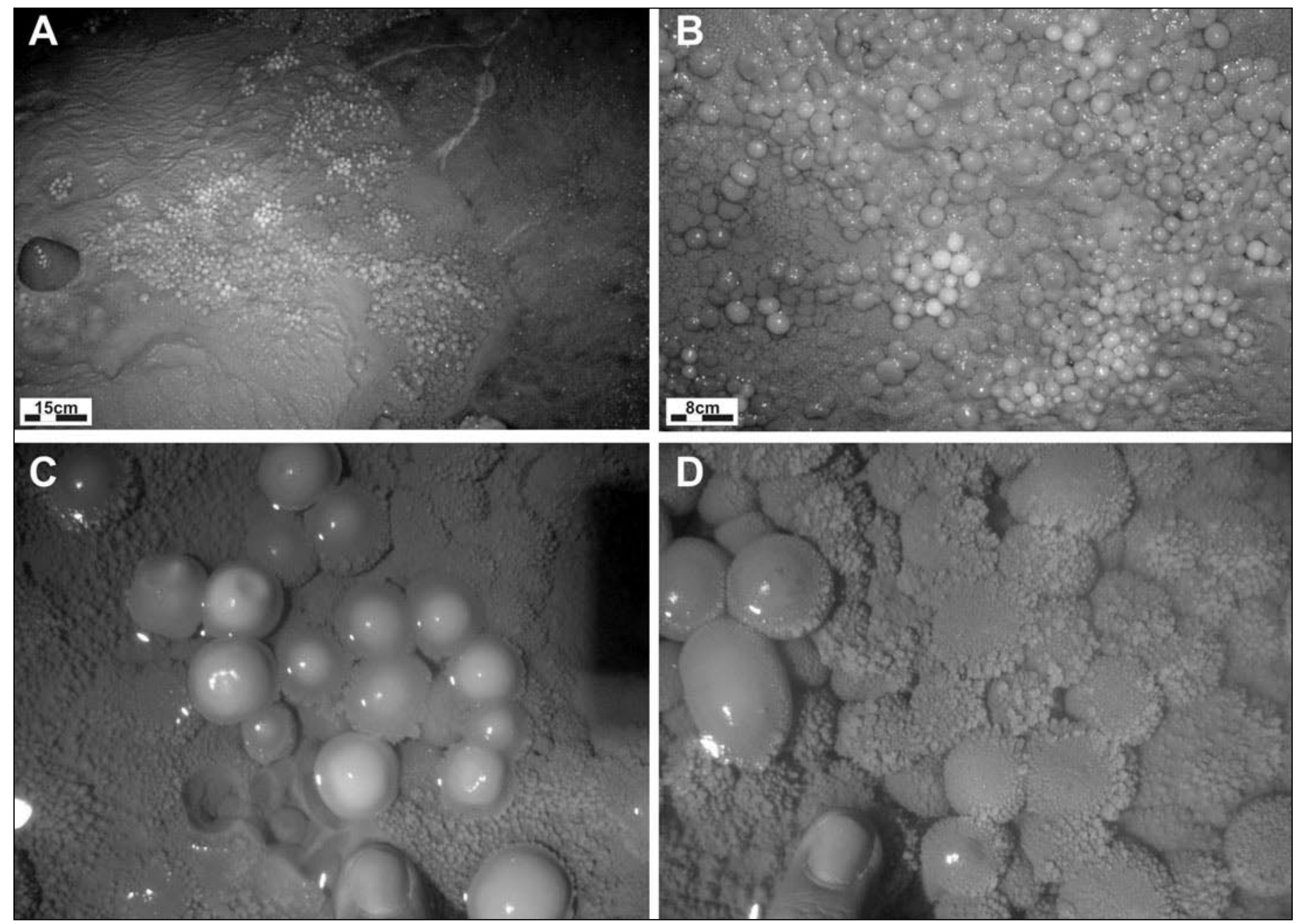

Fig. 3. Photographs showing the spot where the cave pearls where found (A, B) (Photos by Sami Karkabi). Macrophotographs showing the cave pearls at a closer zoom (C, D). Note that some pearls are well polished $(C)$ others are more or less crenulated (D).

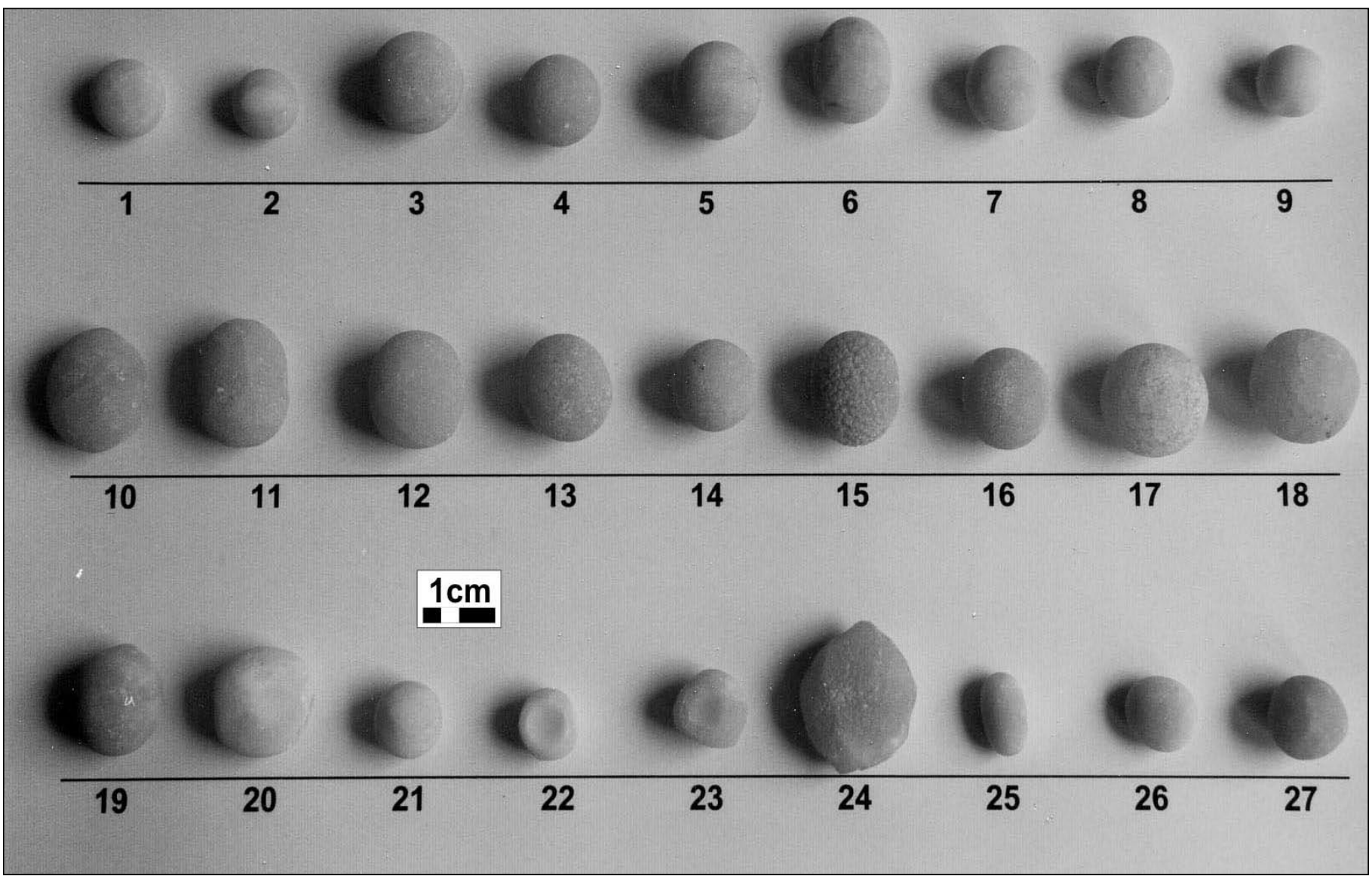

Fig. 4. The twenty-seven cave pearls collected from the Kanaan cave. The sizes of the cave pearls range between 1 and $3 \mathrm{~cm}$. 


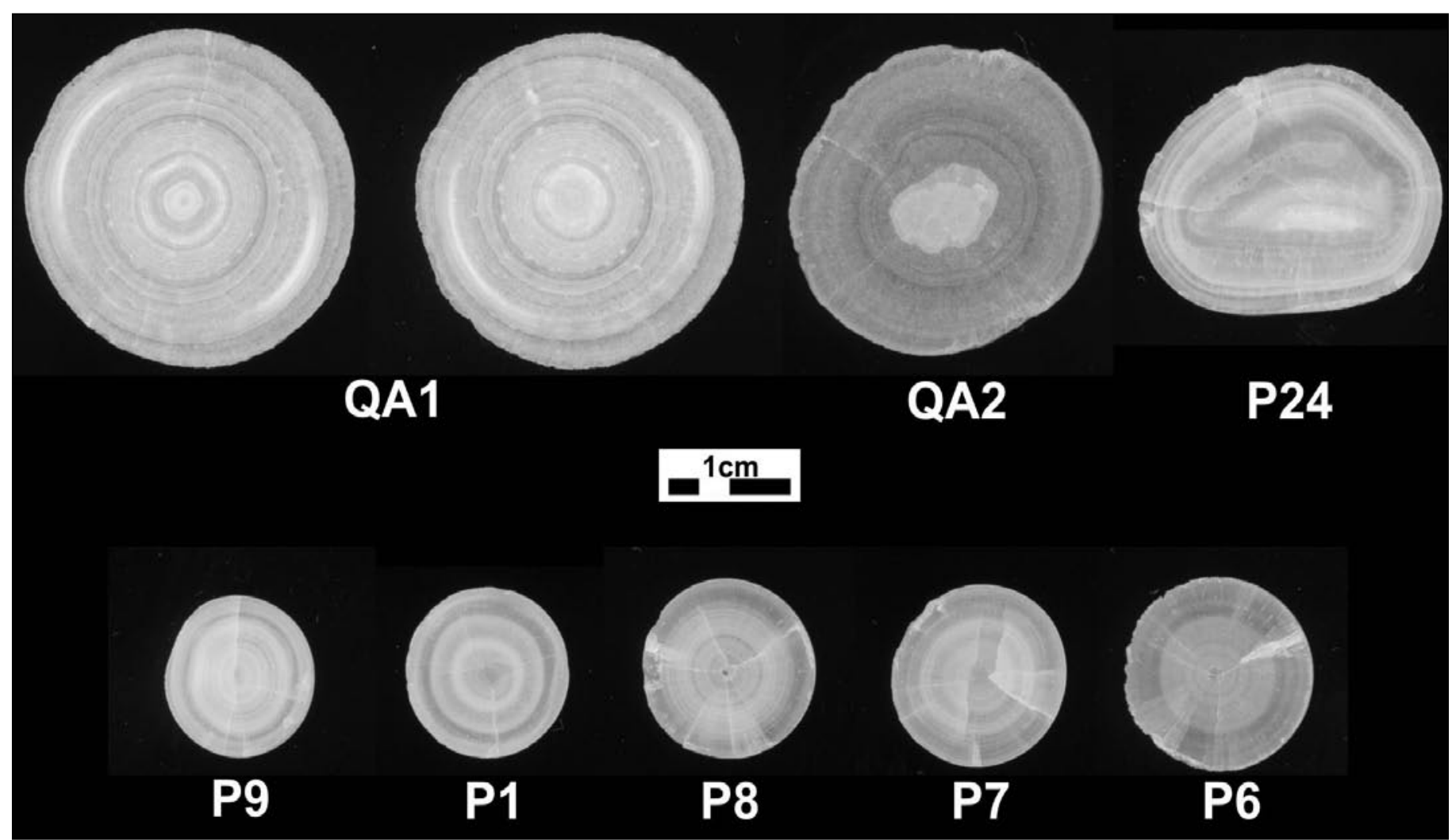

Fig. 5. Scanned polished cut-faces of some cave pearls from the Kanaan cave. Note that [QA1] and [QA2] are not from the Kanaan cave - these are added for reference.
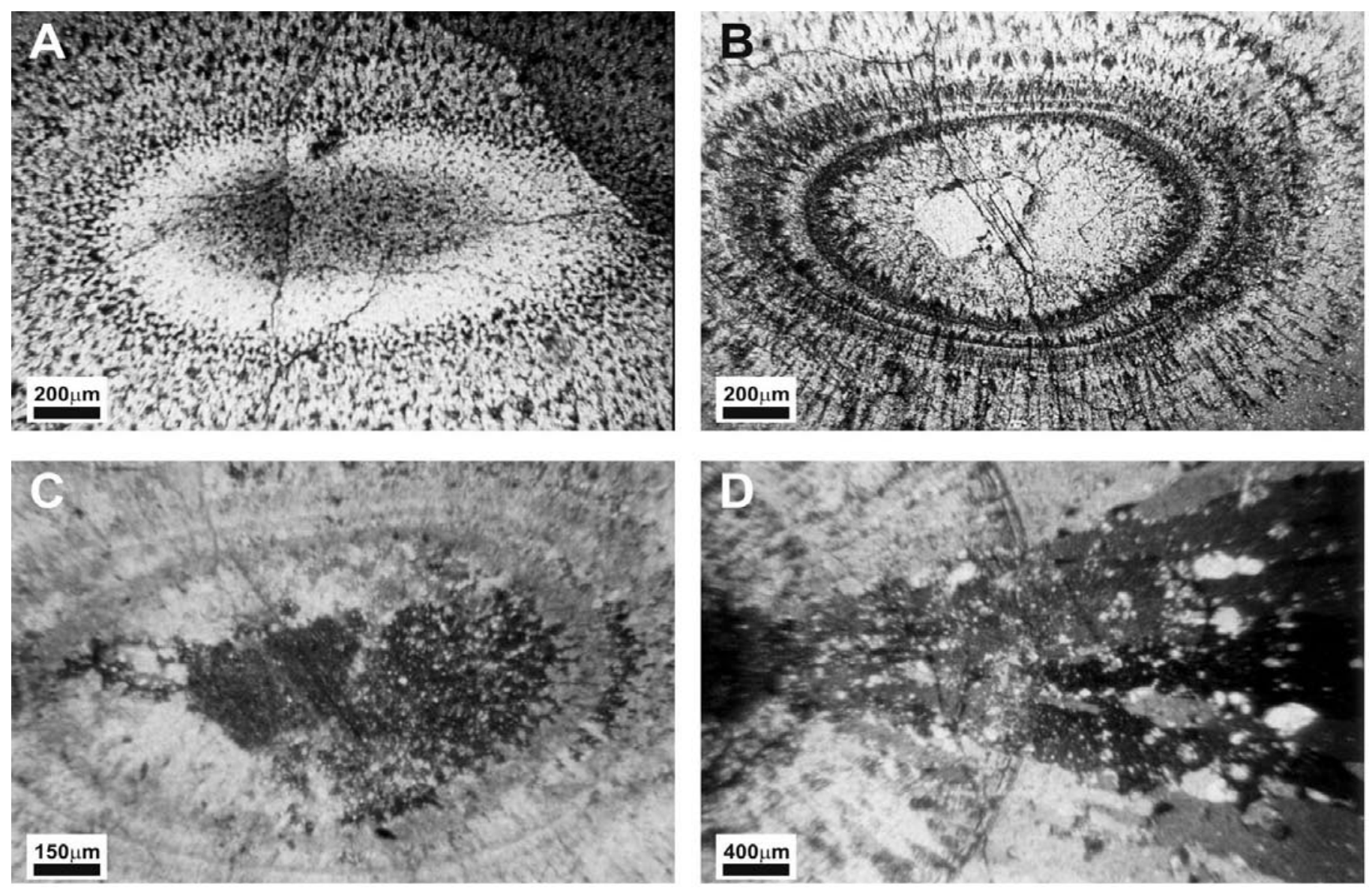

Fig. 6. Photomicrographs illustrating the main petrographic characteristics of the cave pearls' nuclei: (A) plane- transmitted light photomicrograph showing a nucleus made-up of brownish terra-rossa, surrounded by clear micritic calcite cortical laminae; (B) plane- transmitted light photomicrograph showing a nucleus made-up of clear micritic calcite and a spar, surrounded with brownish impurities-rich laminae; (C) crossedpolarized photomicrograph showing $(B)$ at a slightly higher magnification - note the uniaxial extinction continuum from the spar through the micritic calcite crystallites and the inner cortical laminae; (D) crossed-polarized photomicrograph showing crystal continuum from the nucleus through the inner micrite laminae to the outer spar laminae. 

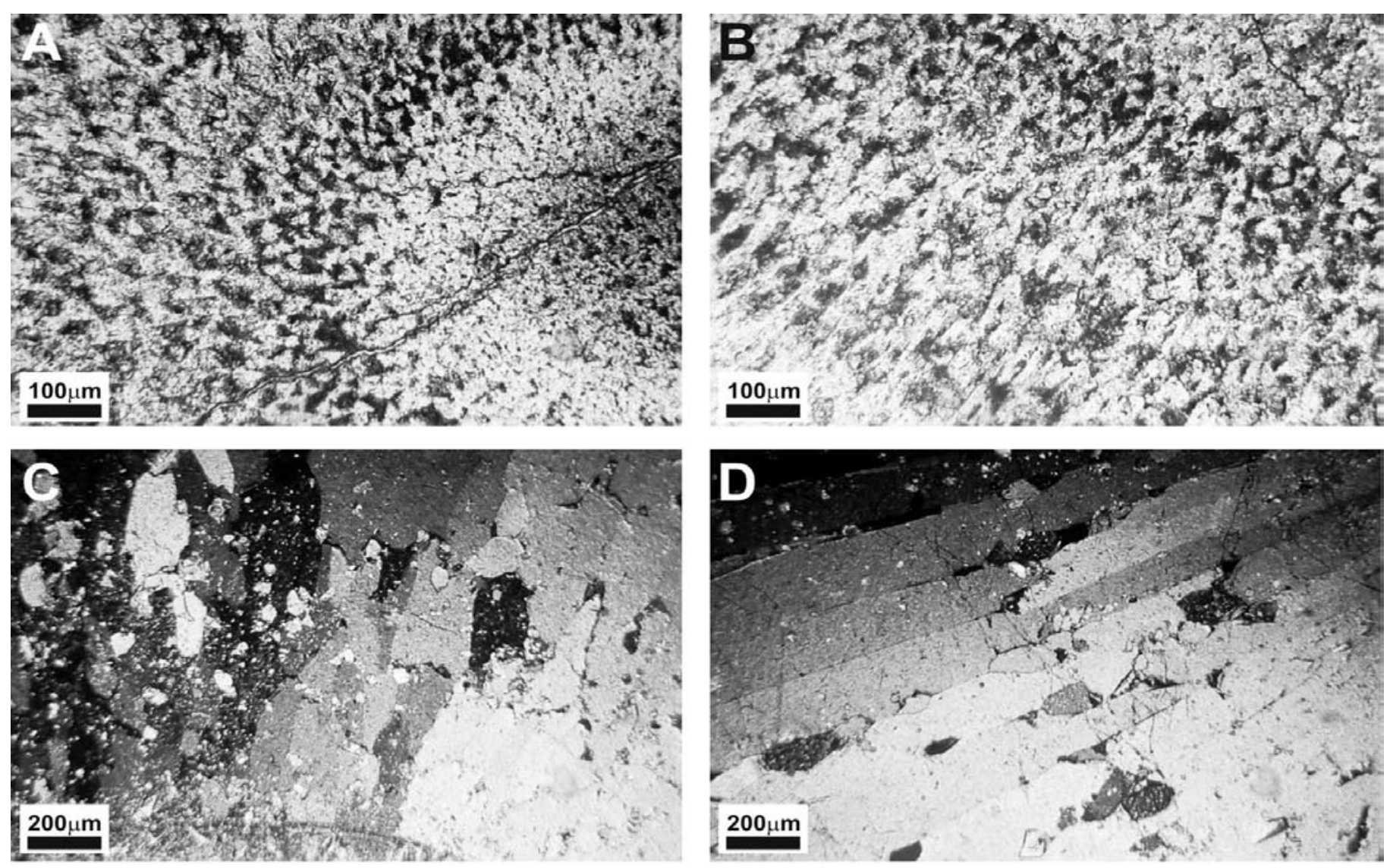

Fig. 7. Photomicrographs illustrating the main petrographic characteristics of the cave pearls' cortical laminae: (A, B) plane- transmitted light photomicrographs showing the fine micritic trigonal calcite crystals - note the dark spots are impurities (Fe-oxides/hydroxides) within intercrystalline porosity; (C, D) crossed-polarized photomicrographs showing the calcite spar laminae with elongated dendritic crystals - note that some crystals are of smaller sizes and seem embedded within the calcite spars.are added for reference.
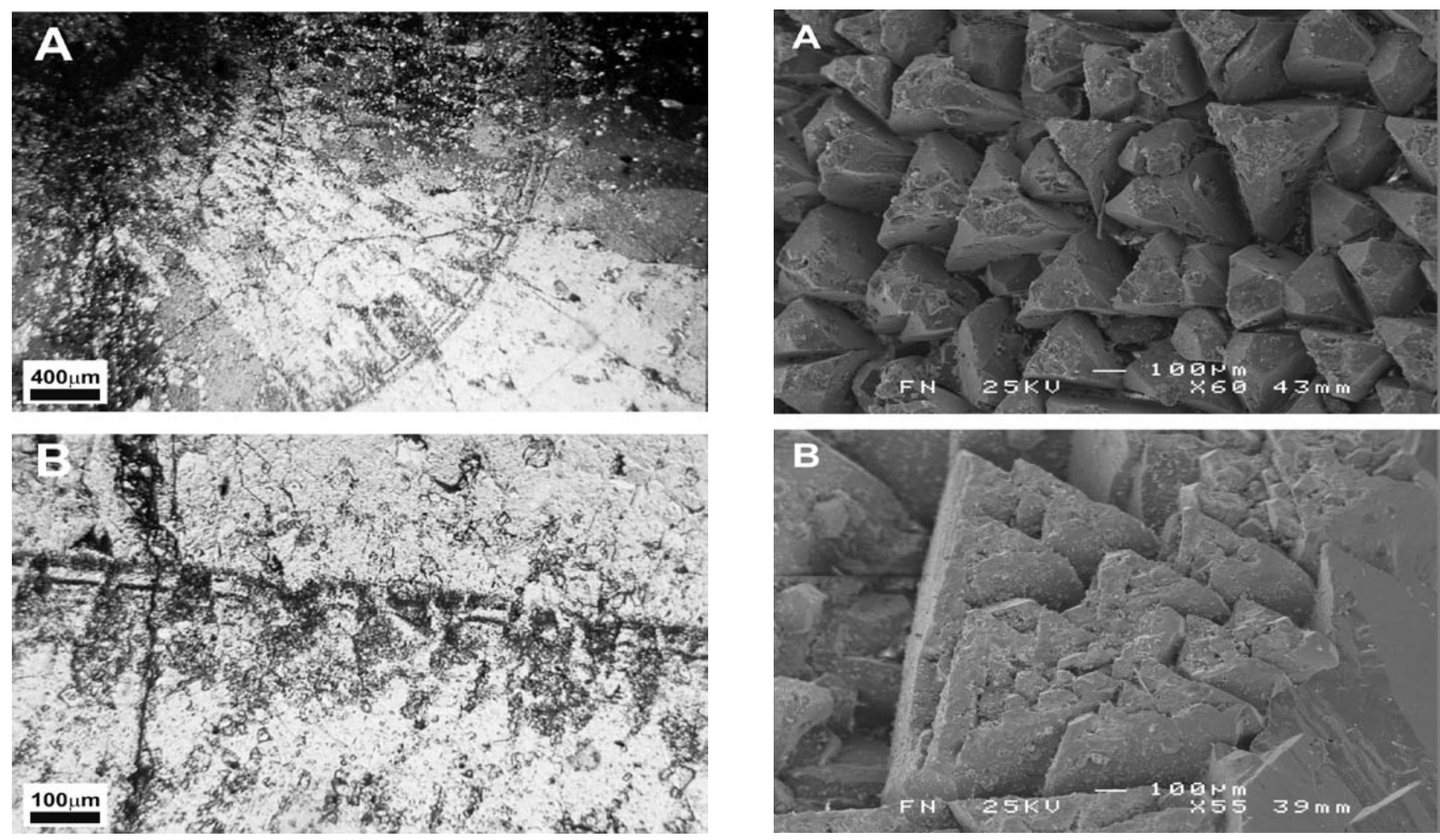

Fig. 8. Photomicrographs showing the transition from inner micrite laminae to outer spar laminae: (A) Crystalline continuum from nucleus to outer layer - note that the mud-envelope is not continuous and faint under crossed-polarized view; (B) transmitted light photomicrograph showing the "purification" of the mud-envelope by the calcite spars, see text for details.

Fig. 9. SEM Photomicrographs showing crystal microfabrics of the external (outermost) layers of the cave pearls: $(A)$ trigonal calcite crystals with rhombohedral apexes and a considerable amount of intercrystalline porosity; (B) aggradational growth of trigonal crystallites within larger trigonal crystals - see text for details. 


\section{$\delta^{18} \mathrm{O}(\% \circ \mathrm{V}-\mathrm{PDB})$}

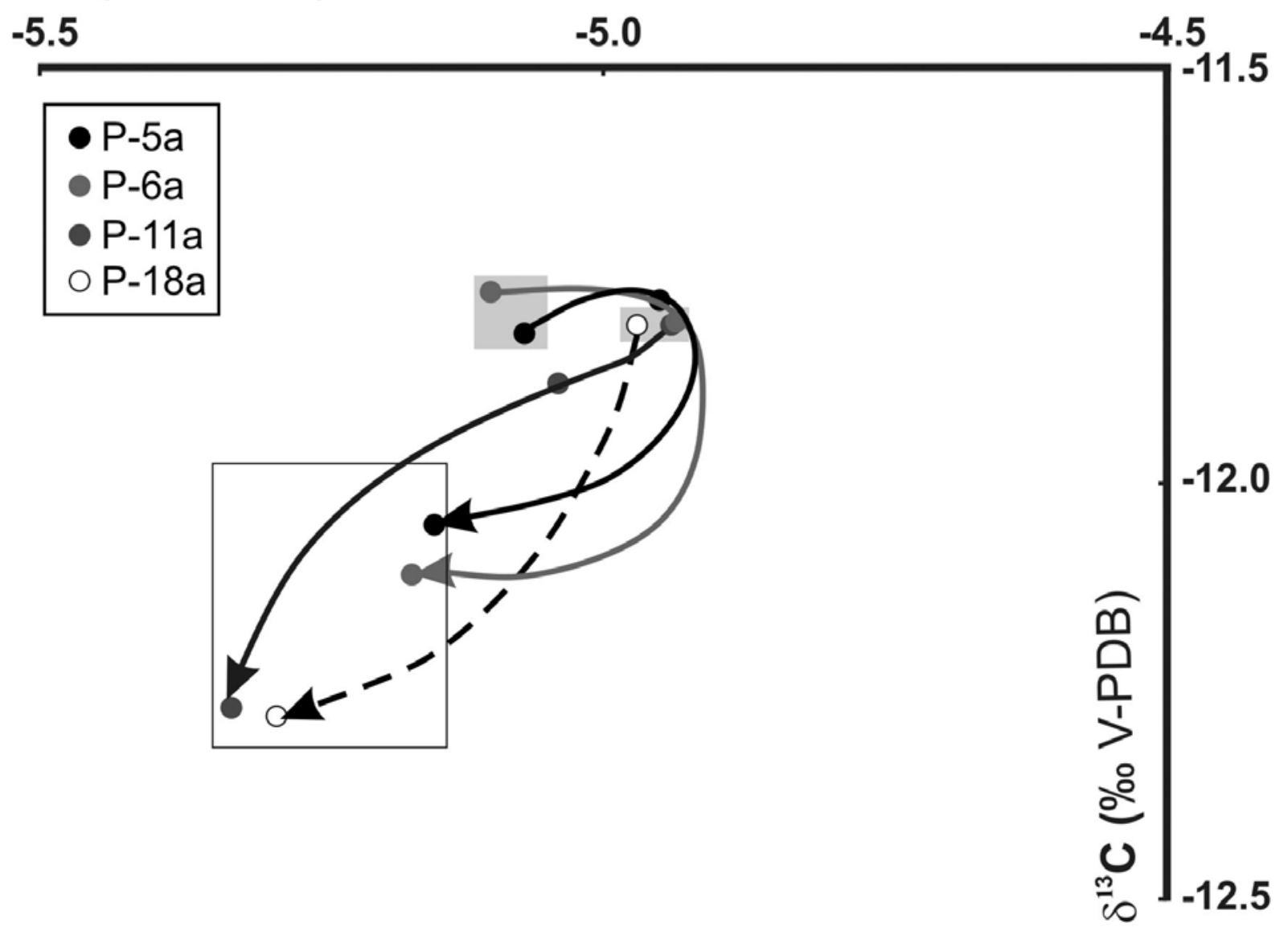

Fig. 10. Oxygen versus carbon isotopic compositions of the nucleus and various cortical laminae from four different cave pearls (Kanaan cave; data from Table 2).

\section{GEOCHEMISTRY}

Table 1 shows the major and trace element composition of the only water sample (A) collected from the rimstone pool located opposite to the location of the pearls (cf. Fig. 2), the inner and outer parts of the cave pearls and a typical spelean calcite from a nearby coastal cave (B). Table 2 shows the $\delta^{18} \mathrm{O}$ and $\delta^{13} \mathrm{C}$ results (in \%o V-PDB) of the cortical laminae from four different cave pearls. The stable isotopic values of a recent spelean calcite (less than 30 years old; precipitated in a tunnel dug in 1971) are also added as a reference for the actual isotopic signature of speleothems in central coastal Lebanon.

Temperature measurements inside the cave were conducted during several visits. The air temperature in the Calcite Gallery (cf. Fig. 2B) is constantly about $20^{\circ} \mathrm{C}$, while the water temperature - measured in the rimstone pool opposite to the location of the pearls, cf. Fig. $2 \mathrm{~B}-$ is about $18^{\circ} \mathrm{C}$ with a $\mathrm{pH}$ of 7.65 . The cave water has a calcium concentration ranging between 54.6 and 57.1 wt.\%, hence it is over-saturated with $\mathrm{Ca}$. The same water possesses about $10 \mathrm{ppm}$ of $\mathrm{Na}$, about $1 \mathrm{ppm}$ of Sr. The measured Fe, Mn, $\mathrm{Zn}$ and $\mathrm{K}$ concentrations in the pool-water were all below the detection limit.

The inner and outer layers of the cave pearls display almost the same $\mathrm{Ca}$ concentrations (ca. about 36.4 wt.\%). The inner layers show a relatively high $\mathrm{Na}$ content ( $54 \mathrm{ppm}$ ) with respect to that of the outer layers (37 ppm). The $\mathrm{Sr}, \mathrm{Fe}, \mathrm{Mn}, \mathrm{Zn}$, and $\mathrm{K}$ contents are almost the same for inner and outer layers, and they are higher than those of the cave water (see Table 1A, B). The insoluble residue (IR\%, after dissolution in 1 molar $\mathrm{HCl}$ ) is slightly higher for the outer layers $(1.2 \mathrm{wt} . \%)$ with respect to that of the inner layers (1.7 wt.\%). When compared to similar trigonal spelean calcite from a nearby coastal cave, $\mathrm{Ca}$ and $\mathrm{Fe}$ contents in the cave pearls are found higher, while $\mathrm{Na}$ and $\mathrm{Sr}$ concentrations are much lower, respectively. The higher $\mathrm{Na}$ and $\mathrm{Sr}$ values could be related to sea-water incursions into that coastal cave.

Figure 10 is a crossplot featuring the $\delta^{18} \mathrm{O}$ versus $\delta^{13} \mathrm{C}$ values for the cortical lamina from different cave pearls collected from the Kanaan cave (Table 2). The data show clearly a decreasing trend for both $\delta^{18} \mathrm{O}$ and $\delta^{13} \mathrm{C}$ from inner to outer cortical layers. The average oxygen isotopic values of the inner layers are in the order of $-5.0 \% \mathrm{~V}-\mathrm{PDB}$, and the corresponding $\delta^{13} \mathrm{C}$ 


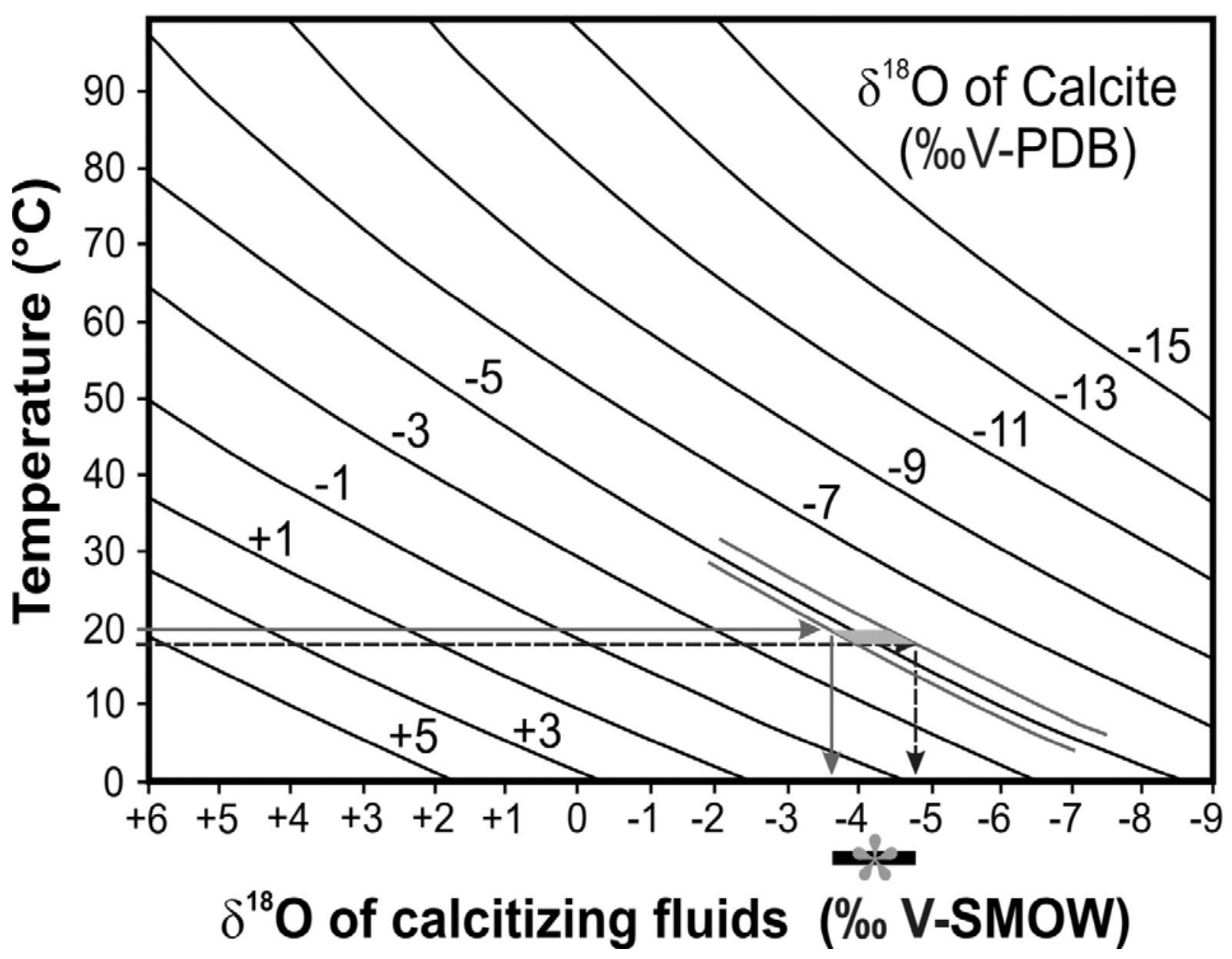

Fig. 11. Graphical display of the oxygen isotopic equilibrium relationship between water, temperature of precipitation and calcite minerals (Woronick \& Land, 1985). Estimation of the $\delta^{18} \mathrm{O}$ composition of the water from which the cave pearls precipitated for temperatures between 18 and $20^{\circ} \mathrm{C}$. The bar on the horizontal axis represents the estimated range for $\delta^{18} \mathrm{O}_{\text {V-smow }}$ composition of the calcitizing fluid (ca. $-4.2 \%{ }_{\text {v-smow }}$ ).

values are around $-11.8 \%$ V-PDB. The outer layers exhibit $\delta^{18} \mathrm{O}$ values ranging between -5.3 and $-5.2 \%$ V-PDB, and $\delta^{13} \mathrm{C}$ between -12.3 and $-12.1 \%$ V-PDB. Recent spelean calcite (wall flowstone), collected from the tunnel dug in 1971 in Jurassic limestones in order to reach the underground network of a nearby Jerita cave, reveals an average $\delta^{18} \mathrm{O}$ value in the order of $-6.1 \%$ V-PDB and $\delta^{13} \mathrm{C}$ value around $9.1 \%$ V-PDB. While this oxygen isotope signature is lighter than those recorded in the Kanaan cave pearls, the carbon isotopic value is less depleted.

\section{DISCUSSION}

According to Baker \& Frostick (1947) and Donahue (1969) the Kanaan spherical to subspherical concretions, which have smooth (polished) and lustruous shining surface, may be termed "cave pearls" and are believed to have formed in agitated water. Donahue (1969) related the genesis of ooid and pisoid grains to the prevailing energy (agitated versus nonagitated conditions). The 'agitated grains' were, thus, characterized by distinct concentric laminations, a pseudo-uniaxial cross (under polarized view), nucleus, smooth polished surfaces, low insoluble residue. All of these characteristics match well with the investigated cave-pearls.

Some of the Kanaan cave pearls contain nuclei surrounded with yellow-brownish aureoles (Fig. 5). These are impurity-rich micritic calcite cortical laminae directly enveloping the nucleus. Such pearls usually include a nucleus with preserved terra-rossa. They do not display uni-axial cross under polarized light. The impurity-rich nucleus and lamina in some pearls could suggest the presence of organic matter as well as clay and oxides/hydroxides. However, their occurrence is relatively limited when compared to the overall volumes of the investigated pearls. Jones \& MacDonald (1989) have discussed some similar micrite laminae in spearls from a cave in the British West Indies. These authors suggested seven alternatives for the origin of the micritic calcite; out of which several scenarios could also work for the Kanaan cave pearls - e.g. inorganic precipitation from cave water, formation of destructive coatings, and/or formation of constructive envelopes. The role of bacteria in the genesis of the Kanaan cave is refuted based on: (1) the cave pearls were found in splash-pools where water 


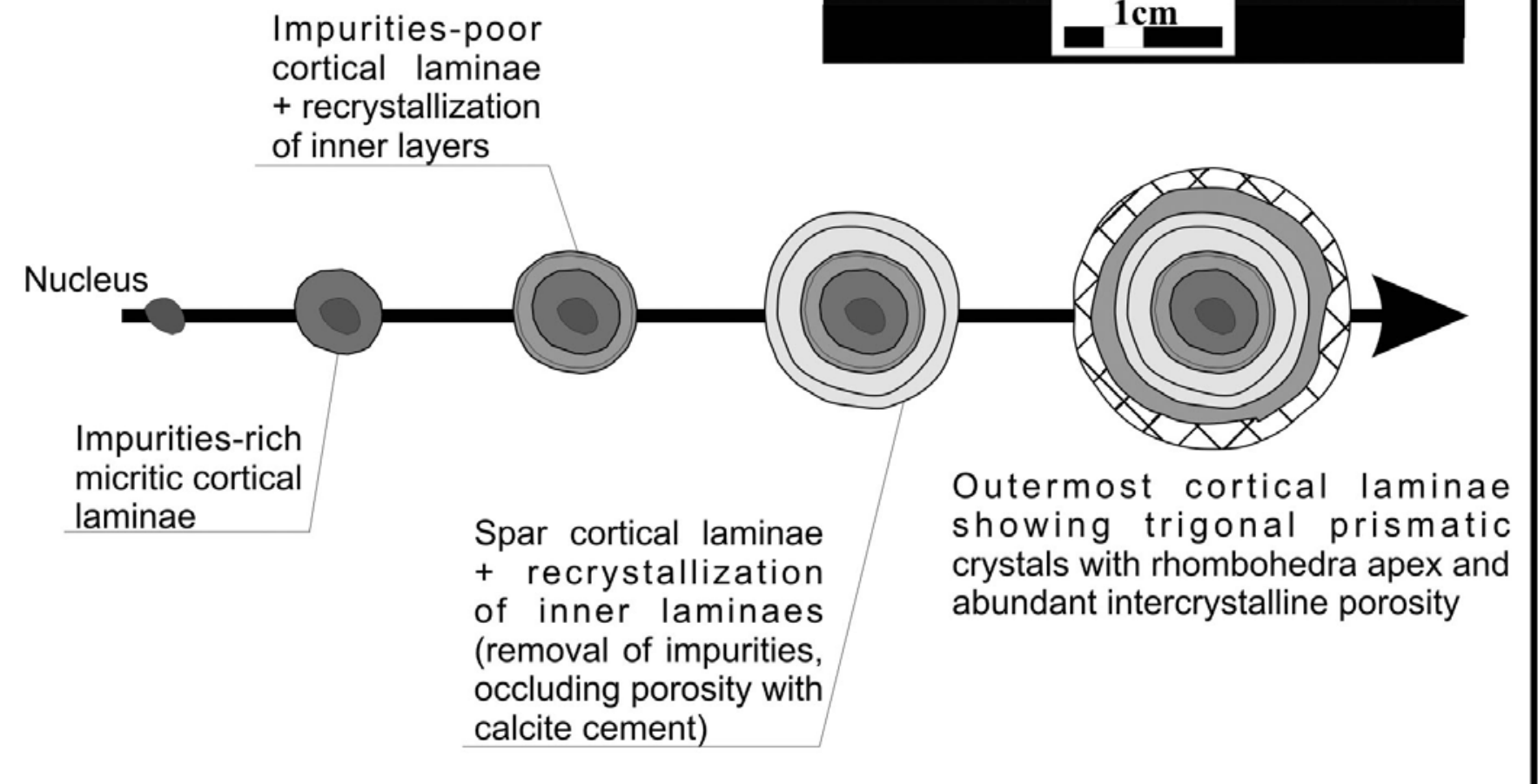

Fig. 12. Simplified schematic illustration describing the major genetic and diagenetic characteristics of the Kanaan cave pearls (inset photo shows two polished cut faces of cave pearls - note the darkish yellow, impurity-rich nuclei aureoles).

motion is considerable and agitation prevails, and (2) no fungal filaments or algal mats have been observed (Jones \& MacDonald, 1989; Gradzinski, 2001). Yet, advanced calcification (and recrystallization) may have effectively destroyed pre-existing bacterial patterns.

The clear micritic calcite crystallites, devoid of impurities, and the presence of sparry calcite crystals with extinction pattern similar/uniaxial to the lengthfast crystals in the surrounding cortical laminae (see Figs. 6 and 7) advocate for recrystallization phases that are believed to have occurred after the formation of the nucleus. This also suggests that the uniaxial cross pattern could be associated with some degrees of recrystallization of the pearls, especially when length-fast calcite crystals are observed in the nucleus and the different cortical lamina (Fig. 7A, B). The spar calcite laminae consist of elongate fastlength calcite spar crystals including some other finer crystals (Fig. 7C, D). This fabric may be explained by growth competition, whereby some crystals grew faster than the others in a radial, outward direction (e.g. Fig. 6D). Alternatively, the spars were formed and then the inter-/ intracrystalline porosity was occluded by another phase of calcite cement. The "feather-like arrangement" (Gradzinski \& Radomski, 1967) has been observed where the nucleus is made up of calcite micrite and spars rather than

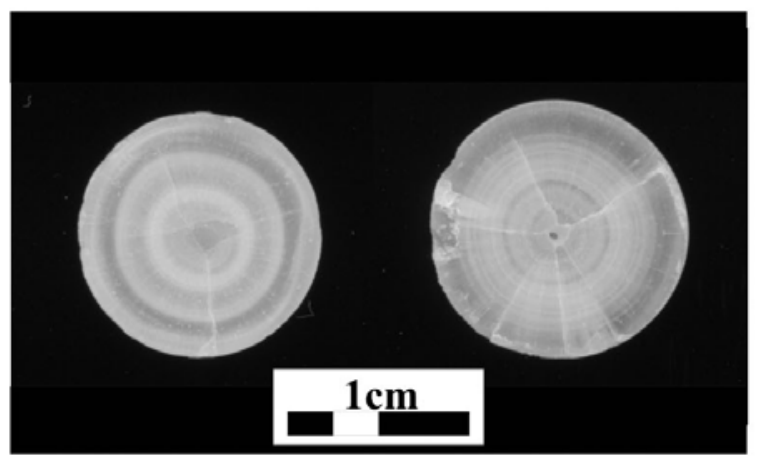

Outermost cortical laminae showing trigonal prismatic crystals with rhombohedra apex and abundant intercrystalline porosity

terra-rossa. Here, the spars seem to invade the inner cortical laminae and the nucleus (Fig. 6). In addition, the mud envelopes (impurity-rich thin layers thought to have covered the pearl during its growth) are incorporated within the length-fast sparry calcite crystals (Fig. 8). Such envelopes appear like 'ghost' inclusions within the calcite and may invoke recrystallization. The sparry calcite represents rapid growth from supersaturated solutions, in response to certain temperature conditions (Jones \& Kahle, 1986; Jones \& MacDonald, 1989). The water in the Kanaan cave's rimstone is highly saturated with $\mathrm{Ca}$ (about $56 \mathrm{wt} . \%$ ) and its temperature is about $18^{\circ} \mathrm{C}$ and the $\mathrm{pH}$ around 7.65.

The outermost layers of the investigated cave pearls consist of crystals having rhombohedra apexes combined to trigonal prism faces, where a considerable amount of intercrystalline porosity remains preserved. Similar crystalline fabrics to the ones discussed by Jones \& MacDonald (1989) are observed in the Kanaan cave pearls. The prismatic trigonal crystals reveal through SEM investigation that they consist of crystallites displaying similar trigonal morphology (Fig. 9B). This aggradational crystal growth, with finer crystals welded together to form coarser crystals, invokes the role of recrystallization as well. Trigonal crystals are believed 
to form exclusively in meteoric vadose environments where the fluids are low in $\mathrm{Ca} / \mathrm{Mg}$ ratios, have low salinity and through $\mathrm{CO}_{2}$ degassing (Binkley et al., 1980; Given \& Wilkinson, 1985). The actual water in the Kanaan cave has a relatively high $\mathrm{Ca} / \mathrm{Mg}$ ratio, suggesting that its low salinity and especially $\mathrm{CO}_{2}$ degassing are the controlling factors for the precipitation of the trigonal crystals. The Jurassic Kesrouane limestones are characterized by $\mathrm{Na}$ concentrations ranging between 103 and 214 ppm (Nader et al., 2004), higher than the Na contents measured in the cave pearls. These rocks have $\mathrm{Sr}$ contents between 110 and 193 ppm (Nader et al., 2004). $\mathrm{Na}$ and $\mathrm{Sr}$ concentrations measured in the investigated cave pearls could have originate from the dissolution of the host-rock (i.e. the Kesrouane limestones) and/or clays and impurities. Iron and manganese contents are believed to be related to the vadose and near-surface environments (cf. Lohmann, 1988).

The oxygen and carbon isotope values from the various layers from four cave pearls showed that a decrease in both $\delta^{18} \mathrm{O}$ and $\delta^{13} \mathrm{C}$ generally prevails from inner to outer layers. The $\delta^{18} \mathrm{O}$ depletion could be related to precipitation from water that has lower $\delta^{18} \mathrm{O}$ values, higher temperature or recrystallization (Lohmann, 1988). Degassing of $\mathrm{CO}_{2}$ may also result in a depletion in $\delta^{13} \mathrm{C}$ values (Given \& Wilkinson, 1985), this is further supported by the trigonal crystalline pattern observed at the outer part of the pearls (see above). The approach of Woronick $\&$ Land (1985) was used in order to estimate the $\delta^{18} \mathrm{O}_{\text {SMow }}$ of the fluid from which the cave pearls precipitated (Fig. 11). The temperature was set between 18 and $20^{\circ} \mathrm{C}$ and the $\delta^{18} \mathrm{O}_{\mathrm{PDB}}$ of the calcite was measured between -5.33 and $-4.94 \%$. This resulted in $\delta^{18} \mathrm{O}_{\text {SMow }}$ around $-4.2 \%$. Note that the $\delta^{18} \mathrm{O}$ of the meteoric water in the eastern Mediterranean region ranges between -6 and -4\% V-SMOW (Emery \& Robinson, 1993).

\section{Cave pearls Genesis/Diagenesis Model}

In general, the nuclei of the investigated pearls show a yellowish aureole with either terra-rossa (preserved at the center) or micrite. The original terra-rossa fabric within the nucleus and the cortical laminae seems to have been destroyed by calcite crystal formation and recrystallization. The micrite calcite cortical laminae which envelope the nuclei, possess relatively higher $\delta^{18} \mathrm{O}$ and $\delta^{13} \mathrm{C}$ values reflecting possible genesis during spelean evaporative conditions, i.e. $\mathrm{CO}_{2}$ degassing (Gradzinski \& Radomski, 1967). The overlying spar calcite laminae resulted from fast precipitation in water highly saturated with $\mathrm{Ca}$ and during further degassing of $\mathrm{CO}_{2}$. This is justified by the relative depletion in $\delta^{18} \mathrm{O}$ and $\delta^{13} \mathrm{C}$ with respect to the inner part of the pearl. Petrographic investigation suggests the predominance of recrystallization in some pearls (especially where the nucleus is devoid of terra-rossa). This is somehow supported by the corresponding lower $\delta^{18} \mathrm{O}$ values. Figure 12 shows two cut-faces of two distinct cave pearls and a sketch presenting a tentative model explaining the formation of the cave pearls and their related recrystallization. After the precipitation of the nucleus and impurityrich, inner micrite cortical laminae, the surrounding spar laminae (length-fast calcite) were formed in water highly saturated with $\mathrm{Ca}$ with enhanced $\mathrm{CO}_{2}$ degassing. Subsequently, trigonal prismatic calcite crystals were precipitated on the outermostlayers. Such process has also triggered selective recrystallization of the inner layers. With each new concentric layer added some inner layers would have severed some degrees of (re)crystallization; e.g. destruction of mud envelopes, occlusion of porosity and crystal aggradations.

\section{CONCLUSIONS}

Based on petrographic and geochemical data of some cave pearls from the Kanaan cave (Jurassic, central Lebanon), the following points can be concluded:

1. The environment of cave pearl formation consists of an agitated splash-pool, with low mud content.

2. The formation of the cave pearls is believed to be due to chemical precipitation of calcite in a fluid over-saturated with calcium - here biogenic related precipitation is dismissed. The internal nucleus and micritic laminae $\left(\delta^{18} \mathrm{O}_{\mathrm{V}-\mathrm{PDB}}:-5.0 \% ; \delta^{13} \mathrm{C}_{\mathrm{V}-\mathrm{PDB}}:-11.8 \%\right)$ include impurity-rich calcite crystal framework; while the surrounding length-fast calcite spar laminae $\left(\delta^{18} \mathrm{O}_{\mathrm{V}-\mathrm{PDB}}:-5.3\right.$ to $-5.2 \% ; \delta^{13} \mathrm{C}_{\mathrm{V}-\mathrm{PDB}}:-12.3$ to $-12.1 \%$ ) have precipitated from water with low salinity, highly saturated with $\mathrm{Ca}$ and during enhanced $\mathrm{CO}_{2}$ degassing.

3. A model for the formation of the Kanaan cave pearls is proposed involving recrystallization which has selectively affected the inner layers of the cave pearls during the growth of the successive outermost layers.

4. The calculated $\delta^{18} \mathrm{O}_{\mathrm{V}-\mathrm{Smow}}$ of the water $(-4.2 \% \mathrm{o})$ matches with data on meteoric water signature for the central eastern Mediterranean region.

\section{ACKNOWLEDGEMENTS}

The author is grateful to Joanna Doummar (Dept. of Geology, American University of Beirut, AUB - Lebanon) for assistance in the fieldwork and in the petrographic analyses. Dr. Rudy Swennen (Katholieke Universiteit Leuven, KUL - Belgium) is thanked for his support, without which this contribution would have never been succeeded. Dr. Michael Joachimski (University of Erlangen - Germany) is thanked for performing the isotopic analyses. H. Nijs (KUL - Belgium) and M. Ijreiss (Dept. of Geology, AUB - Lebanon) are also acknowledged for the technical assistance. This work is partially sponsored by the Katholieke Universiteit Leuven (Afd. Fysico-chemische geologie). The Spéléo-Club du Liban is acknowledged for providing data related to the Kanaan cave (central Lebanon). Critical reviews and valuable comments made by Dr. Calaforra, an anonymous reviewer and the editor (Dr. De Waele) have improved the presentation and content of this contribution, and are greatly appreciated. 


\section{REFERENCES}

Abdul-Nour H., 1991 - Perles cubiques. Liban Souterrain (Bulletin du Groupe d'Etudes et de Recherches Souterraines du Liban), 3: 64-65.

Baker G. \& Frostick A.C., 1947 - Pisolites and ooliths from some Australian caves and mines. Journal of Sedimentary Petrology, 17: 39-67.

Beydoun Z.R., 1988 - The Middle-East: Regional geology and petroleum resources. Scientific Press, London, 292 p.

Binkley K.L., Wilkinson B.H. \& Owen R.M., 1980 Vadose beachrock cementation along a southeastern Michigan marl lake. Journal of Sedimentary Petrology, 50: 953-961.

Choppy J., 1991 - Perles des Cavernes Cubiques et Polyedriques. Al-Ouat'Ouate (Revue Libanaise de Spéléologie et de Karstologie), 6: 43-47.

Donahue J., 1969 - Genesis of oolite and pisolite grains. Journal of Sedimentary Petrology, 39: 1399-1411.

Dubertret L., 1955 - Carte géologique du Liban au 1/200000 avec notice explicative. République Libanaise, Ministère des Travaux Publiques, Beirut, $74 \mathrm{p}$.

Dubertret L., 1975 - Introduction à la carte géologique au 1/50000 du Liban. Notes et Mémoires sur le MoyenOrient, 23: 345-403.

Edgell H.S., 1997 - Karst and hydrogeology of Lebanon. Carbonates and Evaporites, 12 (2): 220-235.

Emery D. \& Robinson A., 1993 - Inorganic Geochemistry: Applications to Petroleum Geology. Blackwell Scientific Publications, Oxford (UK), 254 p.

Folk R.L. \& Assereto R., 1976 - Comparative fabrics of length-slow and length-fast calcite and calcitized aragonite in a Holocene speleothem, Carlsbad Cavers, New Mexico. Journal of Sedimentary Research, 46 (3): 486-496.

Given R.K. \& Wilkinson B.H., 1985 - Kinetic controls of morphology, composition, and mineralogy of abiotic sedimentary carbonates. Journal of Sedimentary Petrology, 55: 108-119.

Gradzinski M., 2001 - Role of bacteria in the growth of cave pearls. In: Proceedings of the $13^{\text {th }}$ International Congress of Speleology - Brasilia 2001, Union International de Spéléologie.

Gradzinski R. \& Radomski A., 1967 - Pisolites from Cuban caves. Rocz. Polsk, Tow. Geol., 37: 243-265.

Hill C. \& Forti P., 1997 - Cave Minerals of the World. National Speleological Society, Huntsville (USA), $463 \mathrm{p}$.

Jones B. \& Kahle C.F., 1986 - Dendritic calcite crystals formed by calcification of algal filaments in a vadose environment. Journal of Sedimentary Petrology, 56: 217-227.

Jones B. \& MacDonald R.W., 1989 - Micro-organisms and crystal fabrics in cave pisoliths from Grand Cayman, British West Indies. Journal of Sedimentary Petrology, 59: 387-396.
KendallA.C. \&TuckerM.E., 1973 -Radiaxialfibrouscalcite: a replacement after acicular carbonate. Sedimentology, 20: 365-389.

Karkabi S., 1991 - La Perle de Caverne Hexagonale. Al-Ouat'Ouate (Revue Libanaise de Spéléologie et de Karstologie), 6: 48-53.

Lohmann K.C., 1988 - Geochemical patterns of meteoric diagenetic systems and their application to studies of paleokarst. In: James N.P. \& Choquette P.W. (Eds.) Paleokarst, Springer-Verlag, New York: 58-80.

Nader F.H., 1998 - Mgharet Kanaan: the temple of speleology. Al-Ouat'Ouate (Revue Libanaise de Spéléologie et de Karstologie), 11: 54-59.

Nader F.H., 2000 - Petrographic and Geochemical Characterization of the Jurassic-Cretaceous Carbonate Sequence of the Nahr Ibrahim Region, Lebanon. M.Sc. thesis, American University of Beirut, Lebanon, 227 p.

Nader, F.H. \& Swennen R., 2004 - Petroleum prospects of Lebanon: Some remarks from sedimentological and diagenetic studies of Jurassic carbonates. Marine and Petroleum Geology, 21: 427-441.

Nader F.H., Swennen R. \& Ottenburgs R., 2003 - Karstmeteoric dedolomitisation in Jurassic carbonates, Lebanon. Geologica Belgica, 6: 3-23.

Nader F.H., Swennen R. \& Ellam R., 2004 - Stratabound dolomite versus volcanism-associated dolomite: an example from Jurassic platform carbonates in Lebanon. Sedimentology, 51: 339-360.

Renouard G., 1955 - Oil Prospects of Lebanon. American Association of Petroleum Geologists Bulletin, 39 (11): 2125-2169.

Saint-Marc P., 1974 - Etude stratigraphique et micropaléontologique de l'Albien, du Cénomanian et du Turonien. In: Note et mémoires sur le Moyen-Orient - Tome XIII, CNRS, Paris/Beirut, 298 p.

Saint-Marc P., 1980 - Le passage Jurassique-Crétacé et le Crétacé inférieur de la région de Ghazir (Liban central). Géologie Méditerranéenne, 7: 237-245.

Wachter E. \& Hayes J.M., 1985 - Exchange of oxygen isotopes in carbon-dioxide - phosphoric acid systems. Chemical Geology, 52: 365-374.

Walley C.D., 1997 - The Lithostratigraphy of Lebanon: A Review. Lebanese Scientific Research Reports, 10: $81-108$.

Walley C.D., 2001 - The Lebanon passive margin and the evolution of the Levantine Neothethys. In: Ziegler P.A., Cavazza W., Robertson A.H.F. \& CrasquinSoleau S. (Eds.) - Peri-Tethys Memoir 6: Peri-Tethyan Rift / Wrench Basins and Passive Margins, Mémoire du Muséum national d'Histoire naturelle, Paris, 86: 407-439.

Woronick R.E. \& Land L.S., 1985 - Late burial diagenesis, Lower Cretaceous Pearsall and Lower Glen Rose formations, South Texas. In: Schneidermann N. \& Harris P.M. (Eds.) - Carbonate Cements, Special Publications of the Society of Economical Paleontology Mineralogists, Tulsa, 36: 265-275. 